\title{
Extinctions of introduced game species on oceanic islands: curse for hunters or conservation opportunities?
}

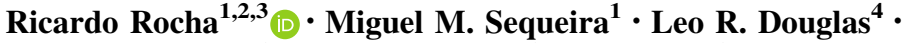 \\ Manuela Gouveia ${ }^{1} \cdot$ Roberto Jardim $^{1} \cdot$ José Jesus $^{1}$ • \\ Holly P. Jones ${ }^{5}$ - Danilo Russo ${ }^{6,7}$
}

Received: 18 February 2017/ Accepted: 26 April 2017/Published online: 5 May 2017

(C) Springer Science+Business Media Dordrecht 2017

In island ecosystems, a considerable portion of the limited conservation resources are often channelled to the eradication of vertebrate invasive species. Since the 1950 s, nearly 900 successful invasive vertebrate eradications have taken place (DIISE 2015) with highly beneficial consequences for insular biodiversity (Caujape-Castells et al. 2010; Jones et al. 2016).

Multiple invasive vertebrates are popular game species on islands worldwide-e.g. the mouflon Ovis gmelini in the Canaries (Nogales et al. 2006) or the Kalij pheasant Lophura leucomelanos in Hawaii (Lewin and Lewin 1984). Yet, despite the detrimental effects of alien wildlife on the native biodiversity, such populations are commonly restocked for recreational hunting. Hunting and biodiversity conservation frequently fall under the responsibility of the same governmental institutions, which have to balance the interests of

Communicated by David Hawksworth.

This article belongs to the Topical Collection: Invasive species.

Ricardo Rocha

ricardo.nature@gmail.com

1 Faculty of Life Sciences, University of Madeira, 9020-105 Funchal, Portugal

2 Faculty of Sciences, Centre for Ecology, Evolution and Environmental Changes, University of Lisbon, 1749-016 Lisbon, Portugal

3 Faculty of Biosciences, Metapopulation Research Centre, University of Helsinki, 00014 Helsinki, Finland

4 Department of Ecology, Evolution \& Environmental Biology (E3B), Columbia University, New York City, USA

5 Department of Biological Sciences and Institute for the Study of the Environment, Sustainability, and Energy, Northern Illinois University, Dekalb, IL 60115, USA

6 Wildlife Research Unit, Dipartimento di Agraria, Università degli Studi di Napoli Federico II, via Università 100, 80055 Portici, Italy

7 School of Biological Sciences, University of Bristol, 24 Tyndall Ave, Bristol BS8 1TH, UK 
hunters versus the institutional responsibility of protecting native, often endemic biodiversity and managing exotic, sometimes invasive taxa. Here, we present introduction history, impacts, and current population status of the European rabbit (Oryctolagus cuniculus) on the island of Porto Santo. We use this case to argue that populations crashes of introduced game species that threaten native insular biodiversity should be seen as opportunities to eradicate such species and restore island ecosystems rather than economical problems to correct through restocking.

\section{Oryctolagus cuniculus as an invasive species}

The European rabbit has been deliberately or accidentally introduced to $>800$ islands worldwide (Flux and Fullagar 1992). Across its native Iberian range, rabbits are a keystone species (Lees and Bell 2008). However, elsewhere, the species has significantly affected the ecosystems to which has been introduced, leading to considerable changes in abundance and composition of native fauna and flora via direct (e.g. herbivory and nest disturbance) and indirect (e.g. competition for food and hyperpredation) pathways (Lees and Bell 2008).

Overgrazing is arguably the most serious threat posed by European rabbits outside their native range (see e.g. Martin et al. 2003 for a description of impacts on the vegetation of Alegranza Island). In island ecosystems, this threat is amplified by the evolutionally naivety of most native plants, which under overgrazing pressure are often outcompeted by non-native plants that have co-evolved with lagomorphs and other mammalian herbivores (Holmgren et al. 2000). Overgrazing has indirectly contributed to the extinction of three bird species restricted to Laysan Island and may reduce food and shelter availability for insular reptiles (Lees and Bell 2008). Introduced populations often cause considerable crop damage (Kontsiotis et al. 2013) and act as reservoirs of antimicrobial resistant genes, which help spread through population expansion (Marinho et al. 2014).

There is therefore undeniable evidence that across its non-native distribution, $O$. cuniculus constitutes a serious ecological, agricultural and public health problem. However, the species is also highly prised game for recreational hunters and is important prey for native (and non-native) carnivore assemblages even outside its native range (Lees and Bell 2008). The interlinkage between ecological and social aspects make rabbit management extremely complex. This complexity is further magnified on island ecosystems that are rich in endemic flora and fauna and whose small populations are intrinsically vulnerable and highly exposed to human pressures.

\section{Rabbit hunting in the island of Porto Santo}

One such island with high endemism is Porto Santo, the oldest island ( $\sim 14$ million years) of the Madeiran Archipelago. Despite its xeric conditions, relatively small size $\left(43 \mathrm{~km}^{2}\right)$ and evident environmental degradation, the island harbours a rich biodiversity, including nearly 250 endemic species (Borges et al. 2008). Like numerous other oceanic islands, human arrival was accompanied by the introduction of several exotic vertebrates, including European rabbits. This rabbit introduction became famous as historical reports mention that a single female that had littered during the voyage was introduced together with her offspring and reproduced so extensively that within a few decades settlers were forced to abandon the island due to widespread crop loss and consequent food shortage (Monod 
1986). In recent years, the island rabbit population has crashed due to the emergence of a more virulent strain of the rabbit haemorrhagic disease virus (Le Gall-Reculé et al. 2011). The Madeira Regional Government, through the Institute of Forests and Nature Conservation, therefore plans to restock Porto Santo's rabbit population using rabbits from the nearby Madeira Island. This decision aims to support the interests of the archipelago's hunting community, for which rabbits are a favoured hunting quarry. However, it also represents a serious threat to the extant native biodiversity of the island, in particular to its threatened flora that over the last century has lost ten native taxa, likely due to intensive grazing by rabbits.

Many island game species are non-native and several, such as the European rabbit, can be considered invasive. Introduction of alien game species are problematic in both mainland and island ecosystems (Carpio et al. 2016). However, the ecological specificities of the latter imply that game management in insular settings should pay even more attention to the pros (e.g. hunting benefits) and cons (e.g. soil erosion and biodiversity damage) of different interventions. This is specially the case for biodiversity hotspots such as Macaronesia and for endemic-rich islands such as Porto Santo. We therefore advocate that extinctions and population collapses of alien game species that pose a serious threat to insular communities should be seen as a conservation opportunity to restore island ecosystems through their complete eradication. On Porto Santo for instance, rabbit eradication would greatly benefit the IUCN Critically Endangered Vicia ferreirensis, a singleisland endemism with an estimated population of less than 50 mature individuals (Carvalho and Osborne 2011). The opportunity costs of not doing so are too high and the long-term consequences may be irreversible. Repeating the same mistakes made in the past today would be unforgivable given the overwhelming knowledge of the detrimental effects alien species have on native biological communities. We therefore expect political decisions to be made in agreement with international guidelines on alien species management (CBD 2002; European Parliament 2014), in consideration of the priceless value that insular biodiversity and its services has not only for local communities-hunters included-but for the whole of humankind.

\section{References}

Borges PAV, Abreu C, Aguiar AF, Carvalho P, Fontinha S, Jardim R, Melo I, Oliveira P, Sequeira MM, Sérgio C, Serrano AR, Sim-Sim M, Vieira P (2008) Terrestrial and freshwater biodiversity of the Madeira and Selvagens archipelagos. In: Borges PAV, Abreu C, Aguiar AF, Carvalho P, Fontinha S, Jardim R, Melo I, Oliveira P, Sequeira MM, Sérgio C, Serrano AR, Vieira P (eds) A list of the terrestrial fungi, flora and fauna of Madeira and Selvagens archipelagos. Direcção Regional do Ambiente da Madeira e Universidade dos Açores, Açores, pp 13-25

Carpio AJ, Guerrero-Casado J, Barasona JA, Tortosa FS, Vicente J, Hillström L, Delibes-Mateos M (2016) Hunting as a source of alien species: a European review. Biol Invasions. doi:10.1007/s10530-0161313-0

Carvalho M, Osborne J (2011) Vicia ferreirensis. The IUCN red list of threatened species 2011: e.T180553A7646823. http://dx.doi.org/10.2305/IUCN.UK.2011-1.RLTS.T180553A7646823.en. Accessed 18 Feb 2017

Caujape-Castells J, Tye A, Crawford DJ, Santos-Guerra A, Sakai A, Beaver K, Lobin W, Florens FV, Moura M, Jardim R, Gómes I (2010) Conservation of oceanic island floras: present and future global challenges. Perspect Plant Ecol Evol Syst 12:107-129. doi:10.1016/j.ppees.2009.10.001

CBD (2002) Guiding principles for the prevention, introduction and mitigation of impacts of alien species that threaten ecosystems, habitats or species, COP 6 Decision VI/23 (Annex)

DIISE (2015) The Database of Island Invasive Species Eradications, developed by Island Conservation, Coastal Conservation Action Laboratory UCSC, IUCN SSC Invasive Species Specialist Group, 
University of Auckland and Landcare Research New Zealand. http://diise.islandconservation.org. Accessed 26 Jan 2017

European Parliament (2014) Report on the proposal for a regulation of the European Parliament and of the Council on the prevention and management of the introduction and spread of invasive alien species. A7-0088/2014

Flux JEC, Fullagar PJ (1992) World distribution of the rabbit, Oryctolagus cuniculus, on islands. Mammal Rev 22:151-205. doi:10.1111/j.1365-2907.1992.tb00129.x

Holmgren M, Avilés A, Sierralta L, Segura AM, Fuentes ER (2000) Why have European herbs so successfully invaded the Chilean matorral? Effects of herbivory, soil nutrients, and fire. J Arid Environ 44:197-211. doi:10.1006/jare.1999.0589

Jones HP, Holmes ND, Butchart SH, Tershy BR, Kappes PJ, Corkery I, Aguirre-Muñoz A, Armstrong DP, Bonnaud E, Burbidge AA, Campbell K (2016) Invasive mammal eradication on islands results in substantial conservation gains. Proc Natl Acad Sci USA 113:4033-4038. doi:10.1073/pnas. 1521179113

Kontsiotis VJ, Bakaloudis DE, Xofis P, Konstantaras N, Petrakis N, Tsiompanoudis A (2013) Modeling the distribution of wild rabbits (Oryctolagus cuniculus) on a Mediterranean island. Ecol Res 28:317-325. doi:10.1007/s1 1284-012-1018-5

Lees AC, Bell DJ (2008) A conservation paradox for the 21st century: the European wild rabbit Oryctolagus cuniculus, an invasive alien and an endangered native species. Mammal Rev 38:304-320. doi:10.1111/ j.1365-2907.2008.00116.x

Le Gall-Reculé G, Zwingelestein F, Boucher S, Le Normand B, Plassiart G, Portejoie Y, Decors A, Bertagnoli S, Guérin JL, Marchandeau S (2011) Detection of a new variant of rabbit haemorrhagic disease virus in France. Vet Rec 168:137-138. doi:10.1136/vr.d697

Lewin V, Lewin G (1984) The Kalij pheasant, a newly established game bird on the island of Hawaii. Wilson Bull 98:634-646

Marinho C, Igrejas G, Gonçalves A, Silva N, Santos T, Monteiro R, Gonçalves D, Rodrigues T, Poeta P (2014) Azorean wild rabbits as reservoirs of antimicrobial resistant Escherichia coli. Anaerobe 30:116-119. doi:10.1016/j.anaerobe.2014.09.009

Martin MC, Marrero P, Nogales M (2003) Seasonal variation in the diet of wild rabbits Oryctolagus cuniculus on a semi-arid Atlantic island (Alegranza, Canarian Archipelago). Acta Theriol 48:399-410. doi:10.1007/BF03194178

Monod T (1986) Sur quelques textes anciens concernat l'histoire naturelle de l'archipel de Madére et des îles Salvages. Bol Mus Mun Funchal 38:97-109

Nogales M, Rodríguez-Luengo JL, Marrero P (2006) Ecological effects and distribution of invasive nonnative mammals on the Canary Islands. Mamm Rev 36:49-65. doi:10.1111/j.1365-2907.2006.00077.x 